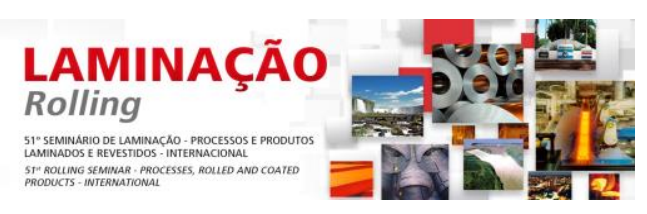

\title{
ULTIMATM - HIGH PERFORMANCE SPUN CAST WORK ROLLS FOR ROLLING LONG PRODUCTS*
}

\author{
Michael Windhager ${ }^{1}$ \\ Karl Heinz Ziehenberger ${ }^{1}$
}

\begin{abstract}
Ultima $^{\mathrm{TM}}$ rolls have been designed for intermediate and finishing stands of rod and bar and small and medium section mills. The rolls and rings are spun cast, with a highly alloyed working layer and a tough nodular iron core. Microstructure and hardness level can be adjusted over a wide range, which allows us to adapt the rolls to differing rolling conditions. After introducing the UltimaTM concept, this paper will describe the results of Ultima ${ }^{\mathrm{TM}}$ rolls achieved in various mill applications, like finish rolling of rebar, and slitting. Special emphasis is given to performance gains when using UltimaTM rolls, compared to standard rolls. This paper also examines the impact of Ultima ${ }^{\mathrm{TM}}$ rolls on mill and roll shop productivity.

Keywords: Rolls; Ultima; Intermediate stand; Finishing stand; Rod section; Bar section.
\end{abstract}

* Technical contribution to the $51^{\text {st }}$ Rolling Seminar - Processes, Rolled and Coated Products, October $28^{\text {th }}$ to $31^{\text {st }}$, 2014, Foz do Iguaçu, PR, Brazil. 


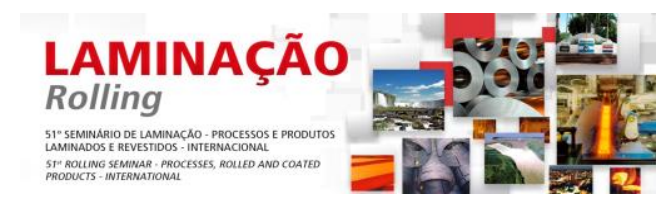

\section{WHAT IS ULTIMATM?}

Ultima $^{\mathrm{TM}}$ is a new family of CC duplex cast work rolls.

The working zone of the roll consists of highly alloyed martensite with a carefully controlled dispersion of high hardness carbides, see fig. 1.

The rolls can be supplied between 65 and $85 \mathrm{ShC}$, and may be ordered within a 5 ShC range (e.g. $75-80 \mathrm{ShC}$ ).

The core and necks consist of high strength nodular cast iron. The typical neck hardness is $45 \pm 3$ ShC.

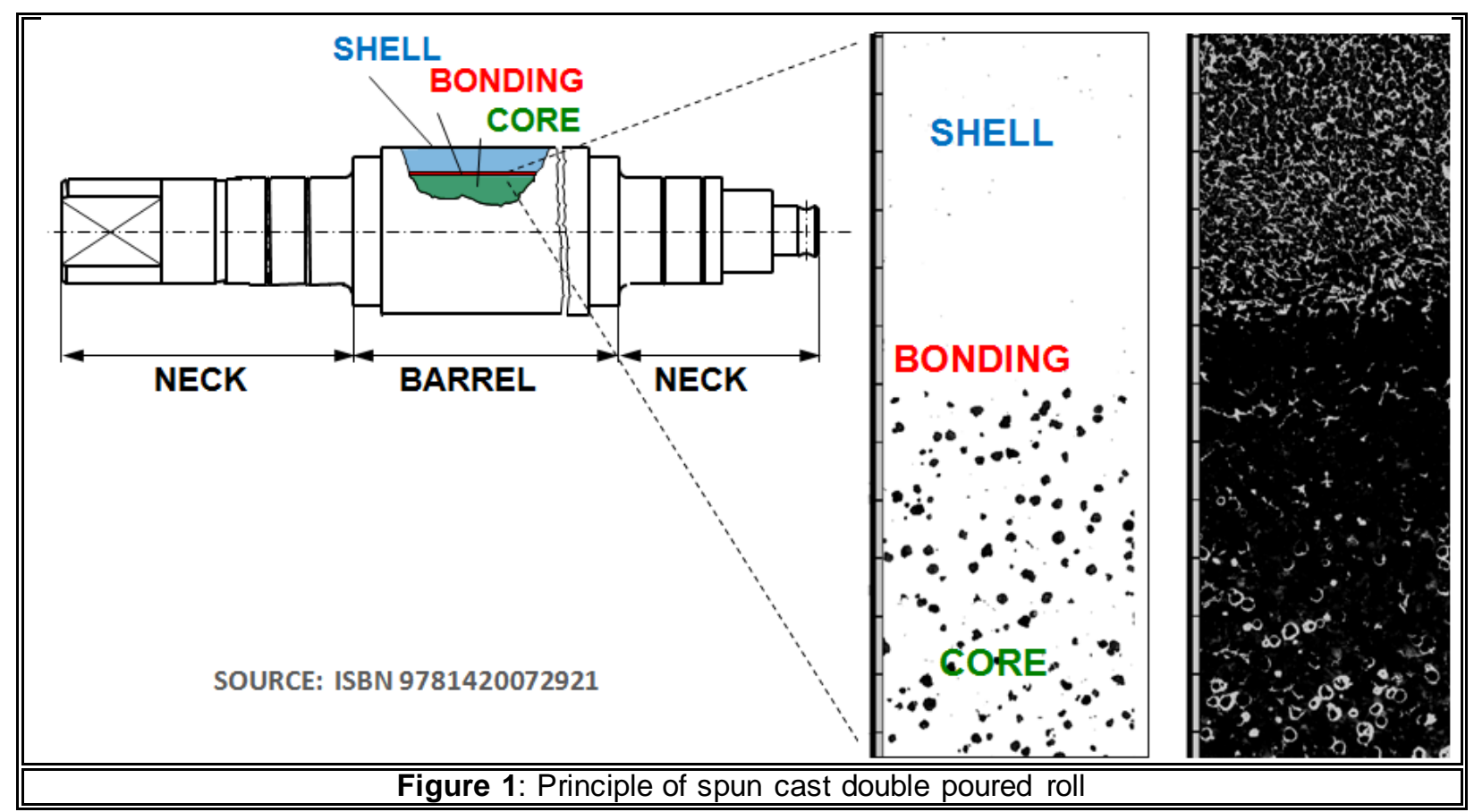

\section{WHAT IS NEW ABOUT ULTIMA ${ }^{\mathrm{TM}}$ ?}

All hot mill work rolls have to provide high wear resistance and fire crack resistance at the same time.

A very high content of hard carbides and highly alloyed martensite can provide maximum wear resistance.

This has consequences for the mills.

Advanced roll materials must be adequately cooled if they are to return maximum performance. They require relatively high water volumes, delivered at the correct pressure. Additionally, the water must be directed, using precisely positioned nozzle arrangements, to guarantee the optimum angle of incidence of the spray.

State of the art cooling arrangements would provide the ideal working situation for a high performance roll. Unfortunately it is not available in many mills, and actual rolling conditions can be far removed from ideal.

This sets a limit for many mills, when it comes to trials with advanced high performance roll grades.

The Ultima ${ }^{\mathrm{TM}}$ concept provides a solution for rolling mills trying to increase performance and output, but suffering from shortcomings in the cooling system.

* Technical contribution to the 51 st Rolling Seminar - Processes, Rolled and Coated Products, October $28^{\text {th }}$ to $31^{\text {st }}, 2014$, Foz do Iguaçu, PR, Brazil. 


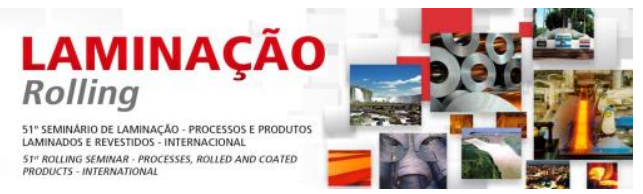

By variation of the carbide/martensite ratio in the shell, the Ultima ${ }^{\mathrm{TM}}$ rolls can be perfectly adjusted to the prevailing working and cooling conditions in the individual mill stand. We recommend starting "on the safe side" with moderate carbide content, and hardness. After gaining experience with the Ultima TM rolls, the amount of carbide in the microstructure and/or the roll hardness can be increased step by step, until the target performance level has been reached.

\section{THE ULTIMA ${ }^{\text {TM }}$ CONCEPT IN DETAIL}

Fig. 2 shows the microstructure of 3 types of Ultima ${ }^{\mathrm{TM}}$, providing a wide variation of carbide content (Ultima 1: 6 - 8\%, Ultima 2: $12-14 \%$, Ultima 3: $20-24 \%$ ) and hardness levels.

The complex carbides found in Ultima ${ }^{\mathrm{TM}}$ rolls exhibit high hardness (above $1400 \mathrm{HV}$ ), and differ significantly from the carbides present in conventional cast iron rolls.

The hardness level of all Ultima ${ }^{\mathrm{TM}}$ variations can be adjusted to the actual mill requirements. The range is from 65 to $85 \mathrm{ShC}$, which is 714 to $830 \mathrm{Ld}$.

The hardness adjustment is obtained during a complex heat treatment process. For production, we need a range of $5 \mathrm{ShC}$ which needs to be specified in the roll order.

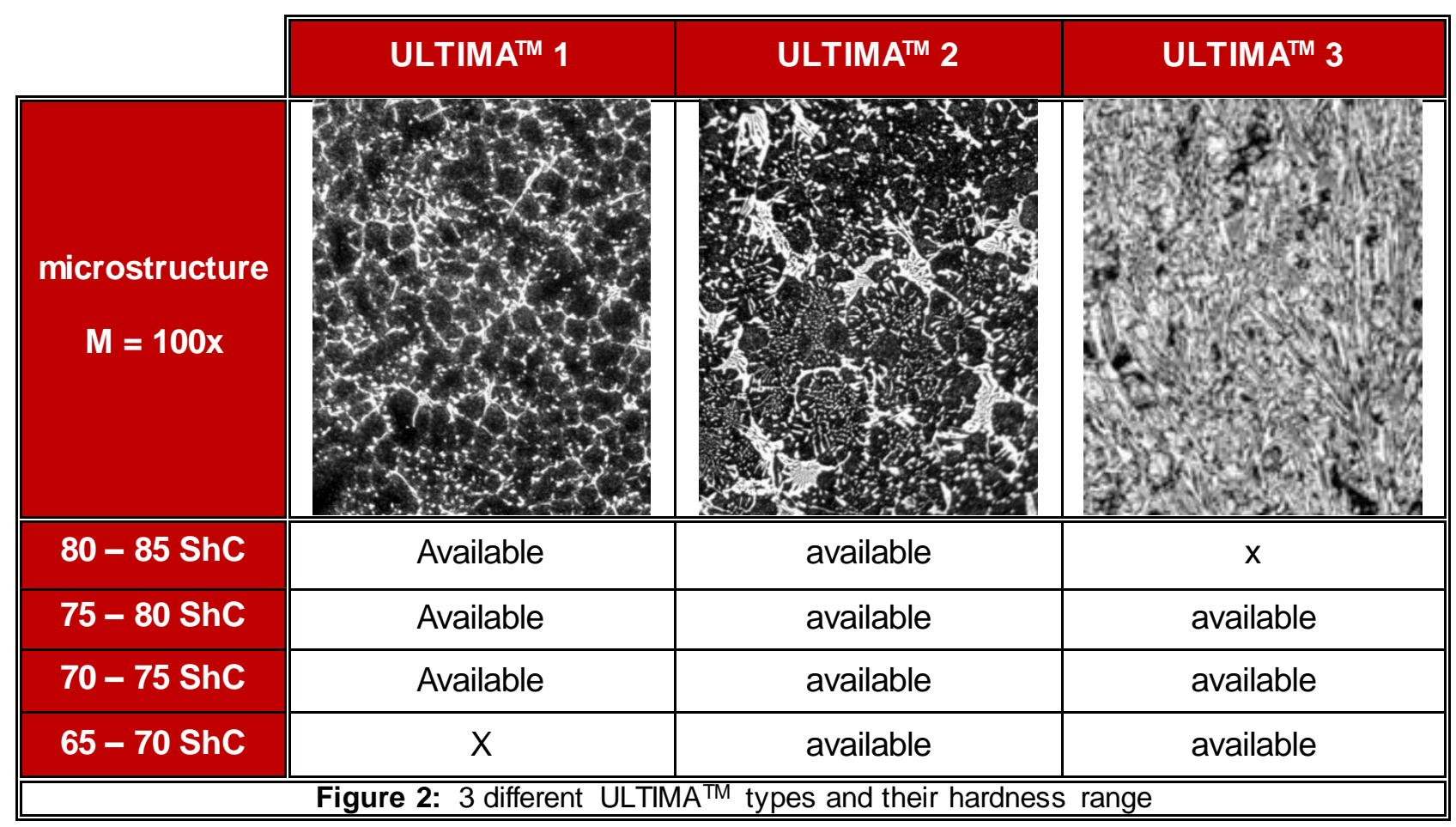

\section{INTRODUCTION OF ULTIMATM TO THE MILLS}

The first UltimaTM rolls were shipped in 2010. The main focus at the beginning was rod and bar mills, mainly dog bone, slitting and finishing.

The rolls designed for slitting and finishing of rebar were also used for earlier stands, with round and oval passes. The experience of most mills showed that rolls that work for slitting and finishing, may not be ideal for round and oval. For "simple" passes, higher wear resistance is required. This lead to the development of various Ultima ${ }^{\mathrm{TM}}$ types as described previously.

* Technical contribution to the 51'st Rolling Seminar - Processes, Rolled and Coated Products, October $28^{\text {th }}$ to $31^{\text {st }}$, 2014, Foz do Iguaçu, PR, Brazil. 


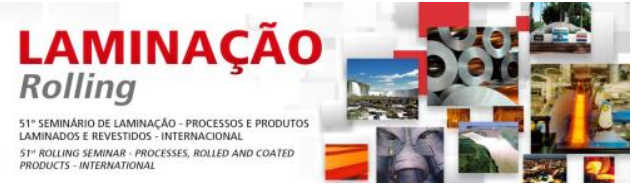

Next step was the introduction of UltimaTM in small section mills. Small angles are rolled successfully in various plants, and now trials with stainless steel angles 1.5"x $1.5 "$ are underway.

Up to now, more than 500 Ultima $^{\mathrm{TM}}$ rolls have been shipped. The rolls are well established in long product rolling, and compete successfully even with carbide rolls and rings.

\section{ROLLING AND COOLING CONDITIONS}

Some high tech roll and ring materials only work well, under particular operating conditions. Usually, they require complex cooling systems with high water pressure (6 bar or more) and bespoke spray systems.

When low rolling speeds are used, many high performance materials do not work to maximum effect. When designing the BRC range of Ultima rolls, we have paid special attention to mills with low rolling speeds and low pressure water cooling systems.

The following table shows some of the applications where Ultima rolls are in service, and gives an idea about the rolling speed and the water pressure of the cooling system.

Table 1.

\begin{tabular}{|c|c|c|c|c|}
\hline pass shape & 2 - 3 bar & 3- 4 bar & 4-6 bar & $>6$ bar \\
\hline Round & $3 \mathrm{~m} / \mathrm{s}$ & $2,5 \mathrm{~m} / \mathrm{s}$ & $2 \mathrm{~m} / \mathrm{s}$ & $1, \mathrm{~m} / \mathrm{s}$ \\
\hline Oval & $3 \mathrm{~m} / \mathrm{s}$ & $2,5 \mathrm{~m} / \mathrm{s}$ & $2 \mathrm{~m} / \mathrm{s}$ & $1 \mathrm{~m} / \mathrm{s}$ \\
\hline Dog bone and slit & & $3,6 \mathrm{~m} / \mathrm{s}$ & & \\
\hline Rebar finishing & & $3,1 \mathrm{~m} / \mathrm{s}$ & & \\
\hline Flat & & $3 \mathrm{~m} / \mathrm{s}$ & $2,5 \mathrm{~m} / \mathrm{s}$ & \\
\hline angles & & $7,5 \mathrm{~m} / \mathrm{s}$ & $5 \mathrm{~m} / \mathrm{s}$ & $4 \mathrm{~m} / \mathrm{s}$ \\
\hline
\end{tabular}

Ultima rolls have been used successfully at low rolling speeds, with very moderate water cooling as well. This data does not necessarily represent the lower limits. Our research in this area continues,- maybe we can go below the mentioned rolling speeds. Time will tell.

\section{MILL EXPERIENCE WITH ULTIMATM ROLLS IN VARIOUS ROLLING APPLICATIONS}

The following examples show the results of Ultima rolls in different mills, operating a wide range of both rolling conditions and product size. We will compare surface finish, wear characteristics and campaign length achieved with Ultima and conventional grades like SG (nodular iron) and AIC (Indefinite chill).

First example:

$\rightarrow$ Bar Mill stands no. 10 to 12 - round / oval pass, rebar finishing - roll size: $400 \mathrm{x}$ $650 \mathrm{~mm}$

* Technical contribution to the 51st Rolling Seminar - Processes, Rolled and Coated Products, October $28^{\text {th }}$ to $31^{\text {st }}$, 2014, Foz do Iguaçu, PR, Brazil. 


\section{LAMINAÇÃO \\ Rolling}

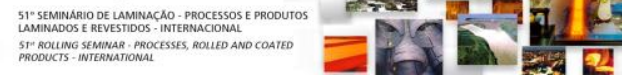

$\rightarrow$ General conditions: stands 10 to 12 - cooling water pressure: 4,5 bar (ca. 65 psi), volume flow: $350 \mathrm{l} / \mathrm{min}$ (ca. 12,4 cfm), rolling speed: 2.6 to $3.1 \mathrm{~m} / \mathrm{s}$ (ca. 9,2 to 10,2 $\mathrm{ft} / \mathrm{s})$

Table 2.

\begin{tabular}{|c|c|c|c|c|c|c|c|}
\hline$\frac{\mathrm{O}}{\bar{N}}$ & $\begin{array}{l}y \\
\frac{8}{8} \\
\frac{10}{2}\end{array}$ & $\begin{array}{l}\text { 옹유 } \\
\text { 은 } \\
\text { 은 }\end{array}$ & 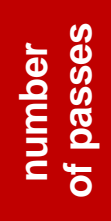 & 일 & 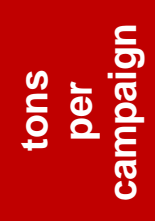 & $\begin{array}{l}\text { 임 } \\
\frac{1}{8} \\
\frac{1}{8}\end{array}$ & 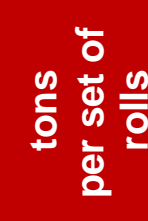 \\
\hline 10 & $\begin{array}{l}\text { round } \\
33 \mathrm{~mm}\end{array}$ & $2,6 \mathrm{~m} / \mathrm{s}$ & 10 & 6.400 & 64.000 & $7,0 \mathrm{~mm}$ & 500.000 \\
\hline 11 & $\begin{array}{c}\text { oval } \\
48 \times 24 \\
\mathrm{~mm}\end{array}$ & $3,1 \mathrm{~m} / \mathrm{s}$ & 10 & 4.800 & 48.000 & $5,5 \mathrm{~mm}$ & 530.000 \\
\hline 12 & $\begin{array}{c}\text { finish } \\
\text { rebar } 28 \\
\mathrm{~mm}\end{array}$ & $3,6 \mathrm{~m} / \mathrm{s}$ & 16 & $\begin{array}{l}950 \\
400 \\
\end{array}$ & $\begin{array}{l}15.200 \\
6.400 \\
\end{array}$ & $\begin{array}{l}5,0 \mathrm{~mm} \\
7,0 \mathrm{~mm}\end{array}$ & $\begin{array}{l}185.000 \\
51.000^{\star}\end{array}$ \\
\hline
\end{tabular}

*: SGP 65 ShC

Figure 3 shows the surface of a Ultima stand 12 bottom roll after rolling 950 t of rebar $28 \mathrm{~mm}$. The surface still looks good, with moderate wear.

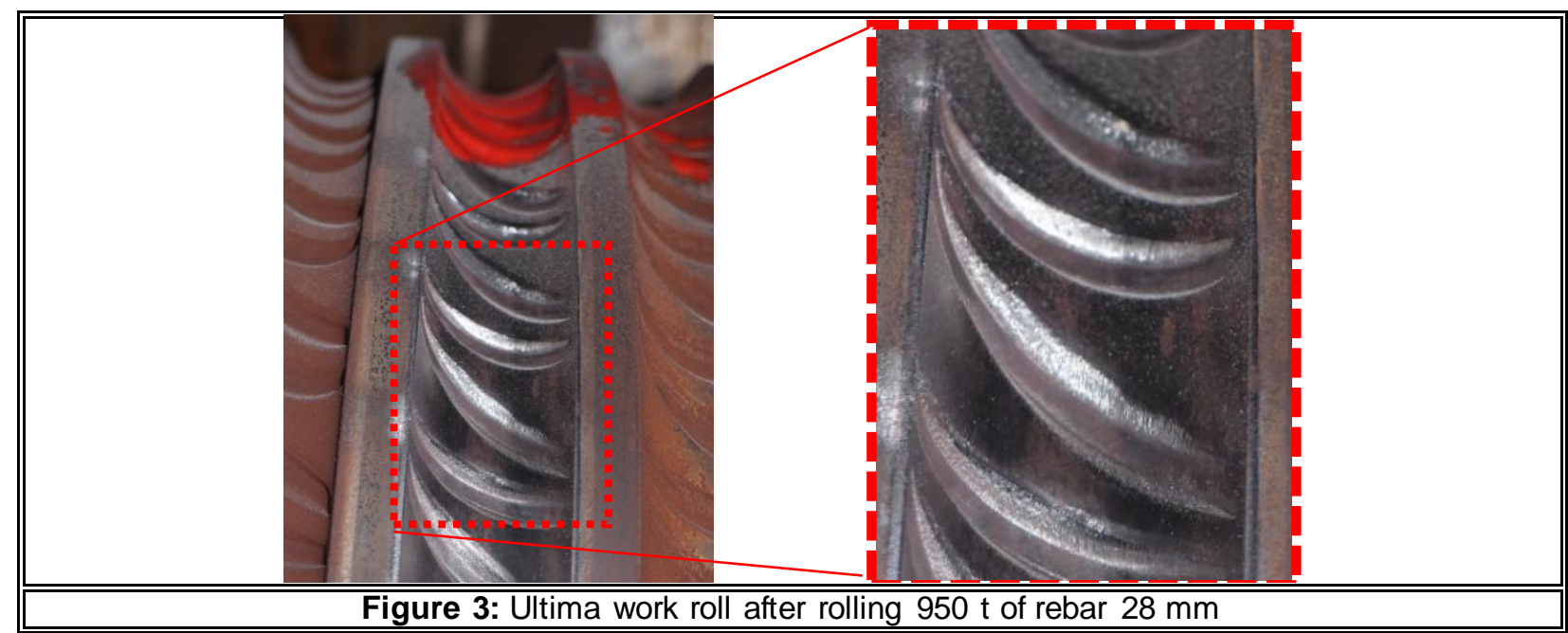

Second example:

$\rightarrow$ Bar Mill dog bone and slitting 2 × 2 3/4" (ca. $19 \mathrm{~mm}$ ) rebar - roll size: $340 \times 500 \mathrm{~mm}$

$\rightarrow$ General conditions: stand 9 dog bone, stand 10 slitting, cooling water pressure: 4 to 5 bar (ca. 58 to $73 p s i$ ), volume flow: $350 \mathrm{l} / \mathrm{min}$ (ca. 12,4 cfm)

A first step of performance improvement was done by changing from standard static cast SGA to double poured CCduplex SGA 68 - 72 ShC, which improved the average campaign length from 960 to 1.500 tons per pass in both stands.

The introduction of HSS led to a significant further improvement:

* Technical contribution to the $51^{\text {st }}$ Rolling Seminar - Processes, Rolled and Coated Products, October $28^{\text {th }}$ to $31^{\text {st }}$, 2014, Foz do Iguaçu, PR, Brazil. 


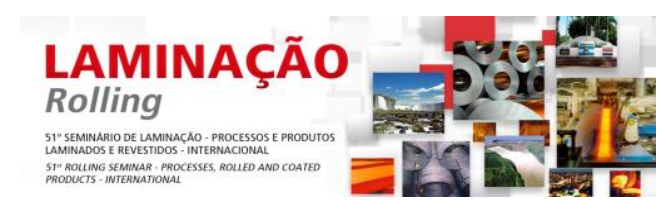

Table 3.

\begin{tabular}{|c|c|c|c|c|c|c|c|c|}
\hline$\frac{8}{\frac{0}{d 0}}$ & $\frac{\$}{2}$ & 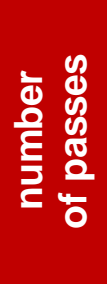 & 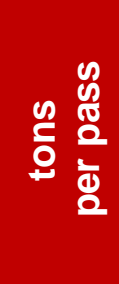 & 을 & $\begin{array}{l}\frac{0}{5} \\
\frac{5}{6} \\
\frac{5}{0}\end{array}$ & 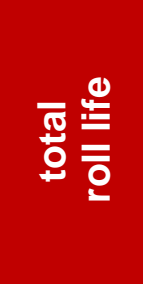 & 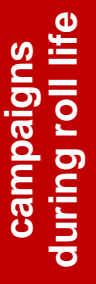 & 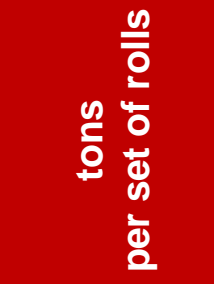 \\
\hline \multicolumn{9}{|c|}{ dog bone: $2 \times 23 / 4$} \\
\hline 9 & $\begin{array}{c}\text { CC } \\
\text { duplex } \\
\text { SGA }\end{array}$ & 6 & 1500 & 9000 & $6 \mathrm{~mm}$ & $60 \mathrm{~mm}$ & 10 & $90.000 \mathrm{t}$ \\
\hline 9 & $\begin{array}{c}\text { ULTIMA } \\
\text { TM }\end{array}$ & 6 & 4800 & 28800 & $4,2 \mathrm{~mm}$ & $60 \mathrm{~mm}$ & 14 & $>400.000 \mathrm{t}$ \\
\hline \multicolumn{9}{|c|}{ slitter: $2 \times 23 / 4$} \\
\hline 10 & $\begin{array}{c}\text { CC } \\
\text { duplex } \\
\text { SGA }\end{array}$ & 6 & 1500 & 9000 & $6 \mathrm{~mm}$ & $60 \mathrm{~mm}$ & 10 & $90.000 \mathrm{t}$ \\
\hline 10 & $\begin{array}{c}\text { ULTIMA } \\
\text { TM }\end{array}$ & 6 & 4800 & 28800 & $4,2 \mathrm{~mm}$ & $60 \mathrm{~mm}$ & 14 & $>400.000 \mathrm{t}$ \\
\hline
\end{tabular}

For an annual production of 500.000 tons, this lead to the following calculation:

Table 4.

\begin{tabular}{|c|c|c|c|c|}
\hline & 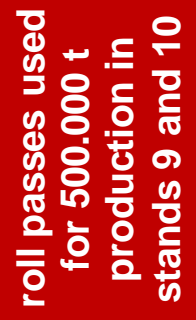 & 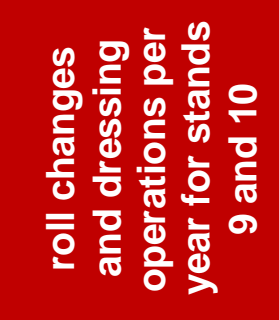 & 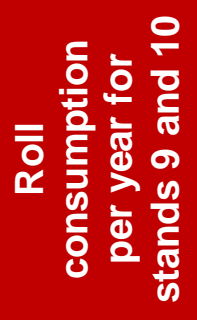 & 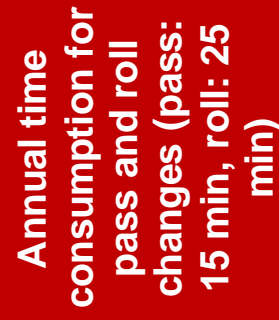 \\
\hline CCduplex SGA & 666 & 111 & 22 & 185 hours \\
\hline ULTIMA & 208 & 35 & 4,8 & 58 hours \\
\hline SAVINGS & - & 76 roll changes & 18 rolls & $\begin{array}{l}127 \text { hour mill } \\
\text { down time }\end{array}$ \\
\hline
\end{tabular}

What is the result of these savings?

$\rightarrow 127$ hours of additional production time in the mill increases the mill output

$\rightarrow 76$ roll changes less means less work load on the roll shop

$\rightarrow 152$ roll machining operations in the roll shop

$\rightarrow$ Preparation of 76 roll stands

In addition to this cost saving potential, we could observe an increase of product quality due to less wear and improved surface condition especially in the dog bone stand, see fig. 4.

* Technical contribution to the 51'st Rolling Seminar - Processes, Rolled and Coated Products, October $28^{\text {th }}$ to $31^{\text {st }}$, 2014, Foz do Iguaçu, PR, Brazil. 


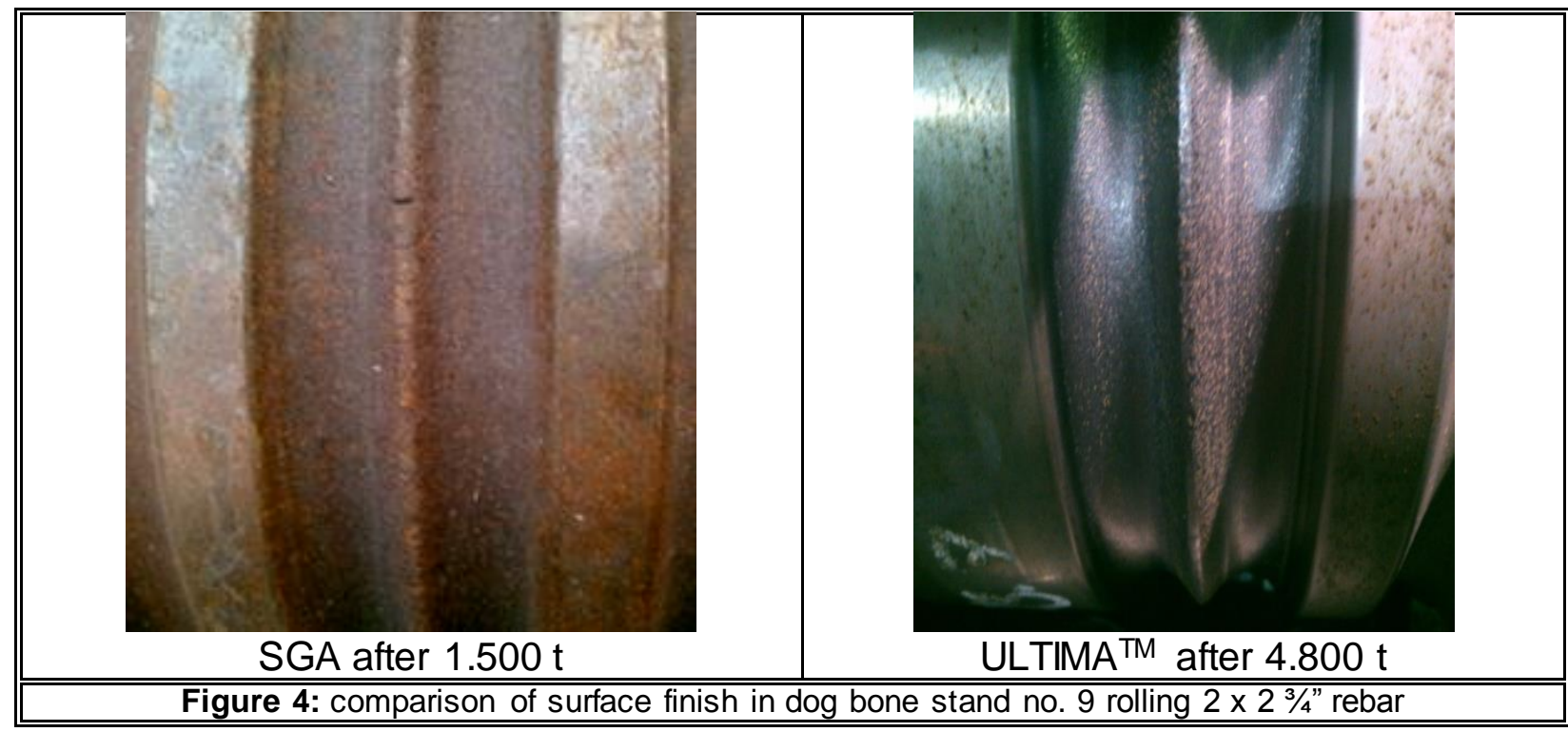

Third example:

$\rightarrow$ Dogbone - 4strand slitter - leader - finisher of rebar \#3 $(3 / 8 "$, ca. $9.5 \mathrm{~mm})$ - roll size: $340 \times 500 \mathrm{~mm}$

$\rightarrow$ General conditions: stands 15 -18, cooling water pressure: 5 to 6 bar (ca. 73 to 87 psi), volume flow: $500 \mathrm{l} / \mathrm{min}$ (ca. $17,7 \mathrm{cfm}$ )

$\rightarrow$ Standard rolls in service: AlC alloy indefinite chill $70-75 \mathrm{ShC}$

$\rightarrow$ Trials were made with: Ultima $75-80 \mathrm{ShC}$

The following results were achieved: product rolled: \#3 rebar $(3 / 8 "$, ca. $9.5 \mathrm{~mm})$

Table 5.

\begin{tabular}{|c|c|c|c|c|c|c|c|c|}
\hline $\begin{array}{l}\frac{0}{50} \\
\frac{15}{\omega}\end{array}$ & $\begin{array}{l}\frac{0}{0} \\
\frac{\mathbb{5}}{5} \\
\overline{\overline{0}}\end{array}$ & 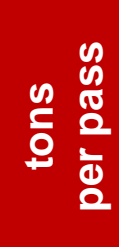 & 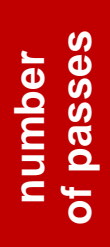 & 을 & 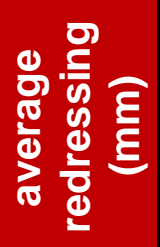 & 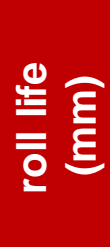 & 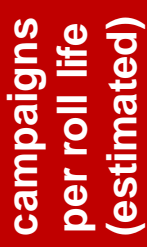 & 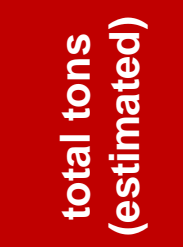 \\
\hline \multicolumn{9}{|c|}{ dogbone (4 strand) } \\
\hline 15 & AIC & 600 & 8 & 4800 & 3,5 & 55 & 15 & 72000 \\
\hline 15 & Ultima & 1800 & 8 & 14400 & 2 & 45 & 22 & $>316800$ \\
\hline \multicolumn{9}{|c|}{ slitter (4 strand) } \\
\hline 16 & AIC & 600 & 8 & 4800 & 3,5 & 55 & 15 & 72000 \\
\hline 16 & Ultima & 1800 & 8 & 14400 & 2 & 45 & 22 & $>316800$ \\
\hline \multicolumn{9}{|c|}{ leader (flat pass) } \\
\hline 17 & AIC & 700 & 7 & 4900 & 3 & 55 & 18 & 88200 \\
\hline 17 & Ultima & 2000 & 7 & 14000 & 2 & 45 & 22 & $>308000$ \\
\hline \multicolumn{9}{|c|}{ finishing (notching pass) } \\
\hline 18 & AIC & 300 & 8 & 2400 & 3,5 & 55 & 15 & 36000 \\
\hline 18 & Ultima & 1200 & 8 & 9600 & 3,5 & 45 & 15 & 144000 \\
\hline
\end{tabular}

* Technical contribution to the 51 October $28^{\text {th }}$ to $31^{\text {st }}$, 2014, Foz do Iguaçu, PR, Brazil. 


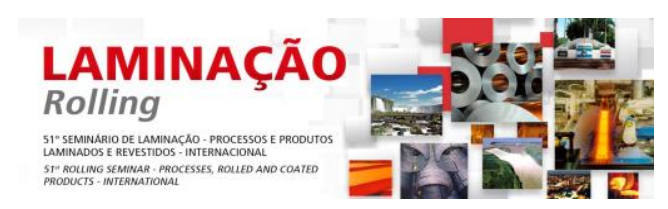

The higher performance of the Ultima rolls is evident.

The use of such rolls has an impact on mill and roll shop operations, and on profitability of the whole plant. Also in this case, a rough estimation was made to calculate savings through use of Ultima rolls.

Roll shop: The roll shop has to remachine about 700 AIC rolls per year. Changing to Ultima would reduce the annual grindings to 210 .

$\rightarrow$ Savings: $2000 \mathrm{hrs}$ machining time

The same applies to the number of mill stands that have to be assembled per year.

210 instead of 700 stand assemblies would reduce the workload on the roll shop by another 2.500 hours!

Mill: 210 roll changes instead of 700 would reduce the mill down time by about 750 hours per year, resulting in about 50.000 t additional production!

\section{SUMMARY}

Ultima $^{\text {TM }}$ rolls have been developed for intermediate and finishing stands of long product mills. Since the introduction in 2010, more than 500 rolls have been delivered, most of them to rod and bar mills. The rolls have proven to be reliable in operation, without the sensitivity exhibited by other high tech products.

Ultima $^{\mathrm{TM}}$ rolls can yield serious performance gains in various applications of long product rolling by:

$\rightarrow$ Significant reduction in roll changes per week/year, and number of machining operations in the roll shop.

$\rightarrow$ Increase of mill availability.

$\rightarrow$ Reduction of roll inventory.

$\rightarrow$ Improved product yield by the reduction of downgraded bars due to chipping of slitting rolls

Existing pass designs can be used, and there are no changes required in the roll machining operations.

Ultima $^{\mathrm{TM}}$ rolls represent a breakthrough in many long product rolling applications.

* Technical contribution to the 51 st Rolling Seminar - Processes, Rolled and Coated Products, October $28^{\text {th }}$ to $31^{\text {st }}$, 2014, Foz do Iguaçu, PR, Brazil. 